\title{
Learning environments research in English classrooms
}

\begin{abstract}
Although learning environments research has thrived for decades in many countries and school subjects, English classroom environment research is still in its infancy. This article paves the way for expanding research on English classroom environments by (1) reviewing the limited past research in English classrooms and (2) reporting the first study of English learning environments in Singaporean primary schools. For a sample of 441 grade 6 students, past research in other subjects was replicated in that a modified version of the What Is Happening In this Class? (WIHIC) questionnaire was cross-validated, classroom environment was found to vary with the determinants of student sex and ethnicity, and associations emerged between students' attitudes and the nature of the classroom environment.
\end{abstract}

Keywords Academic efficacy $\cdot$ Attitudes $\cdot$ English language education $\cdot$ Learning environments $\cdot$ Primary-school students $\cdot$ What Is Happening In this Class? (WIHIC)

\section{Introduction}

The learning environment encompasses social, psychological and pedagogical contexts where learning occurs and which affects student achievement and attitudes (Fraser 2012). Research on learning environments can be traced to the ideas of Lewin (1936) and Murray (1938) in non-educational settings, which were extended to classrooms by Walberg and Moos (Moos and Trickett 1974; Walberg and Anderson 1968). Since then, learning environments research has grown exponentially in many countries, including Asia, and has been facilitated by the availability of numerous economical and extensively-validated questionnaires for assessing 
classroom environments (Fraser 2012, 2014) and teacher-student interpersonal relationships (Wubbels and Brekelmans 2005, 2012) that have been used successfully across countries.

"Few fields of educational research have such a rich diversity of valid, economical and widely-applicable assessment instruments as does the field of learning environments" (Fraser 1998, p. 7). The pioneering research of Walberg and Moos involved the use of, respectively, the Learning Environments Inventory (LEI, Walberg and Anderson 1968) and Classroom Environment Scale (CES, Moos and Trickett 1974). For several decades, the Questionnaire on Teacher Interaction (QTI, Goh and Fraser 2000; Wubbels and Brekelmans 2012) has been used in more than a dozen countries. In order to assess the learning environment of specific settings, researchers designed specific-purpose questionnaires such as the Science Laboratory Environment Inventory (SLEI, Fraser, Giddings and McRobbie 1995), Constructivist Learning Environment Survey (CLES, Taylor, Fraser \& Fisher 1997), Individualized Classroom Environment Questionnaire (ICEQ, Fraser 1982) and TechnologyRich Outcomes-Focused Learning Environment Inventory (TROFLEI, Aldridge and Fraser 2008). An instrument for assessing computer-assisted learning environments was designed by Teh and Fraser (1995) and a recent questionnaire that includes dimensions related to assessment is the Constructivist-Oriented Learning Environment Survey (COLES, Aldridge et al. 2012).

The most-frequently used classroom environment questionnaire around the world today is the What Is Happening In this Class? (WIHIC, Aldridge et al. 1999; Cohn and Fraser 2016; Helding and Fraser 2013). For example, Fraser (2012) tabulated 21 studies that had used the WIHIC in Australia and Taiwan, the UK, Canada, Indonesia, Singapore, India, South Africa, Korea, the United Arab Emirates and the USA. More recently, Khine et al. (in press) tabulated 24 studies that had used the WIHIC in Australia, China, Greece, Indonesia, 
Israel, Jordan, Qatar, Singapore, Turkey, Uganda, the United Arab Emirates and the USA. The WIHIC was used in the study reported later in the current article.

In past learning environment studies in various subject areas, dominant lines of research have included the use of learning environment dimensions as criteria of effectiveness in evaluating educational programs (e.g. Koh and Fraser 2014; Spinner and Fraser 2005; Zaragoza and Fraser 2017) and investigations of associations between the classroom environment and student outcomes (Fraser and Butts 1982; Fraser and Kahle 2007; McRobbie and Fraser 1993). Other researchers have used classroom environment questionnaires in the work of school psychologists (Burden and Fraser 1993), in investigating differences between students' actual and preferred learning environments (Byrne, Hattie and Fraser 1986; Fraser and Fisher 1983) and identifying the classroom environments created by exemplary teachers (Fraser and Tobin 1987).

One of the most promising practical applications of classroom environment instruments is for providing feedback to teachers engaged in action research aimed at improving their learning environments. This approach was first described by Fraser (1981a) and has been the focus of Fraser and Aldridge's (2017) recent review. Studies that have employed these techniques for improving classrooms include Aldridge, Fraser and Sebela (2004) and Yarrow, Millwater and Fraser (1997).

Reviews of research clearly show that past learning environment studies have involved numerous subject areas, but especially science and mathematics, and have focussed mainly on the middle- and high-school levels and higher education. However, there have been fewer learning environment studies involving the subject of English and the primaryschool level, which both were distinctive foci in our study.

Objectives 
1. Our first aim is to review the limited past research on learning environments in English classrooms.

2. Our second objective is to report the first study in Singapore of the assessment, determinants and effects of the learning environment in primary-school English Language classrooms. Specifically, this research aimed to:

i. modify and validate a questionnaire for assessing learning environment in primary English Language classrooms

ii. investigate two determinants of learning environment, namely, student sex and ethnicity

iii. investigate associations between students' attitudes and learning environment.

\section{Method}

After reviewing past studies of English learning environments (summarised in Table 1), we used a survey research design to frame the procedure. To assess English classroom environments, we chose and modified the What Is Happening In this Class? (WIHIC, Fraser, McRobbie and Fisher 1996), which is the most frequently-used learning environment questionnaire around the world today. Some of the many studies that cross-validated the WIHIC and found it useful in research applications are Chionh and Fraser (2009), Afari, Aldridge, Fraser and Khine (2013) and Dorman (2003). We modified the WIHIC by replacing two items in Teacher Support to better suit the Singaporean context. Six of the WIHIC's seven original scales (Student Cohesiveness, Teacher Support, Involvement, Task Orientation, Cooperation and Equity) were retained as being suitable for measuring students' perceptions of the environment of Singaporean English classes. 
To permit investigation of the effects of the learning environment on students' attitudes, we also included and adapted an enjoyment scale from the Test of Science Related Attitudes (TOSRA, Fraser 1978, 1981b) and a self-efficacy scale from the Morgan-Jinks Student Efficacy Scale (MJSES, Jinks and Morgan 1999). We named these scales Attitude to English Language and Academic Efficacy. All scales administered in Singapore were in the English language.

\section{Data Sources}

Our sample comprised 441 grade 6 students in 22 classes (about 35-40 students each) mainly from four typical 'neighbourhood' schools (localised government-run schools). Because these students were aged around 12 years, they had achieved sufficient maturity and accumulated enough primary-school experience to be able to provide meaningful questionnaire responses.

\section{Analyses and Results}

Review of past research on English classroom environments

Table 1 summarises a total of 19 studies (in descending chronological order) of learning environments in the English classrooms. This research was conducted in a limited range of countries -5 in Iran, 6 in China, 3 in USA and 1 each in Jordan, Indonesia, Ethiopia, Malaysia and Singapore. Mainly well-known and widely-established instruments were modified and used: What Is Happening In this Class? (WIHIC, Aldridge, Fraser and Huang 1999) in 8 studies; Questionnaire on Teacher Interaction (Wubbels and Brekelmans 2005) in

5 studies; Constructivist Learning Environment Survey (CLES, Taylor, Fraser and Fisher 
1997) in 2 studies; Classroom Environment Scale (CES, Moos and Trickett 1974) in 4 studies; College and University Classroom Environment Inventory (CUCEI, Fraser, Treagust and Dennis 1986) in 2 studies; a questionnaire based partly on My Class Inventory (MCI, Sink and Spencer 2005) in 1 study; Constructivist-Oriented Learning Environment Survey (COLES, Aldridge, Fraser, Bell and Dorman 2012) in 1 study; and a self-developed questionnaire based largely on WIHIC (Liu and Fraser 2013) in 1 study.

A noteworthy observation about the past English environment studies in Table 1 is that generally they cross-validated well-known questionnaires that had been developed and used in other subject areas, as well as replicating the associations between learning environment and student outcomes frequently reported for other subjects.

\section{Our Study in Singapore}

Validity of WIHIC

Responses to our version of the WIHIC from 441 students were analysed to check factor structure and internal consistency reliability. Principal axis factoring with varimax rotation and Kaiser normalization was conducted to determine the factorial validity of the WIHIC. The criteria for the retention of any item were factor loadings of at least 0.40 on its own scale and less than 0.40 on all of the other scales. All WIHIC items satisfied these criteria except one item from Student Cohesiveness, which was subsequently excluded. All other items were retained in their original six scales. Table 2 shows the factor loadings and that the percentage of variance ranged from $2.77 \%$ (Student Cohesiveness) to $32.91 \%$ (Cooperation), with a total of $55.61 \%$. Eigenvalues ranged from 1.33 to 15.79 . 
To check the internal consistency reliability of each WIHIC scale, the alpha coefficient (Cronbach 1951) was estimated with the individual as the unit of analysis and reported at the bottom of Table 3. Alpha coefficients for our sample ranged from 0.81 to 0.92 for different WIHIC scales, which are similar to those found for Australian and Taiwanese students by Aldridge, Fraser and Huang (1999) and which are satisfactory according to De Vellis (1991).

Sex and ethnicity as determinants of learning environment perceptions and attitudes

Before investigating determinants of classroom environment and attitude-environment associations, we first checked the validity of our Attitude to English Language and Academic Efficacy scales with our sample of 441 Singaporean students. Using the same procedures as those described above for the WIHIC, we conducted principal axis factor analysis with varimax rotation and Kaiser normalisation to check the structure of the two scales. When the same criteria for item retention were applied (a factor loading of at least 0.40 on its own scale and less than 0.40 on the other scale), all items satisfied the criteria and therefore were retained. Table 3 shows that, for these two attitude scales, the percentages of variance accounted for were $55.55 \%$ and $17.31 \%$ (total of $68.86 \%$ ) and eigenvalues were 8.49 and 2.77. The bottom of Table 3 shows that the alpha reliability was 0.90 for Attitude to English Language and 0.95 for Academic Efficacy.

Sex differences were examined using MANOVA with the six WIHIC scales and two attitude scales as dependent variables and sex as the independent variable. Because the multivariate test using Wilks' lambda criterion yielded statistically significant sex differences for the set of dependent variables as a whole, the univariate ANOVA results were interpreted separately for each of the dependent variables as shown in Table 4. 
As well as investigating the statistical significance of sex differences on each scale, effect sizes were used to describe the magnitude, or educational importance, of differences. Cohen's $d$ effect size, which is calculated by dividing the difference between males' and females' means by the pooled standard deviation, expresses a sex difference in standard deviation units (Cohen 1988). Table 4 reports scale means and effect sizes.

Table 4 shows that statistically-significant sex differences existed for Task Orientation and Cooperation, with female perceiving their classrooms as more task-oriented and cooperative than male students did. Effect sizes of 0.35 to 0.37 standard deviations for these two scales suggest that these sex differences were of modest magnitude. Table 4 also shows that the difference in scale means between males and females (although small in most cases) was consistently in the same direction for all scales. Relative to males, females had somewhat more positive learning environment, attitude and efficacy means.

To investigate ethnic differences (Chinese vs Malay students) in learning environment and attitude scales, we conducted similar MANOVA/ANOVAs and calculated similar effect sizes. Table 5 reveals statistically-significant ethnic differences for the two WIHIC scales of Teacher Support and Involvement and also for Attitude to English Language, with Malay students having more positive scores than Chinese students for each of these scales. Effect sizes for ethnic differences for these three scales were medium and ranged from 0.32 to 0.53 standard deviations (Cohen 1988). The means in Table 5 suggest that, relative to Chinese students, Malay students tended to have somewhat more positive scores across all learning environment and attitude scales.

Associations between students' attitudes and learning environment 
Table 6 shows associations between WIHIC scales and the two attitude scales. Simple correlations were used to indicate the strength of the association between each WIHIC scale and each attitude. Multiple regression analysis was conducted for each attitude measure to provide information about the joint influence of correlated WIHIC scales on attitude and academic efficacy. The standardised regression coefficient was used to describe the association between an outcome and a particular WIHIC scale when the effect of the other WIHIC scales was kept constant.

Simple correlation analysis revealed that all learning environment scales were significantly and positively correlated with both Attitude to English Language and Academic Efficacy. For Attitude to English Language, correlations ranged from 0.25 (Student Cohesiveness) to 0.46 (Equity). For Academic Efficacy, correlations ranged from 0.27 (Teacher Support) to 0.39 (Involvement).

The multiple correlation for the set of WIHIC scales was 0.54 for Attitude to English Language and 0.44 for Academic Efficacy, and was statistically significant in each case. To determine which of the learning environment scales contributed most to these multivariate associations, the standardized regression coefficients were examined. Teacher Support, Task Orientation and Equity were positively, significantly and independently associated with Attitude to English Language, whereas Involvement and Equity were significant independent predictors of Academic Efficacy (Table 6).

\section{Significance and conclusion}

The main contribution of this article to the field of learning environments is that it paves the way for future expansion of research on English classroom environments by reviewing the limited past research for this subject area, cross-validating in English classrooms a modified 
version of a questionnaire that has proved valid for numerous other subjects (i.e. the WIHIC), and replicating past research in other subjects into some determinants and effects of classroom environment. Also, while most past research on learning environments has focused on older students, our research involved primary-school children around 12 years old.

Our review of 19 past studies of English classroom environments in 8 different countries revealed two general patterns. First, well-known learning environment questionnaire that had been developed and used in other subject areas were cross-validated in English classrooms. Second, the consistent relationships found between student outcomes and learning environment perceptions in other subjects generally were replicated in English classrooms. Our study involving 441 grade 6 students in English classes in Singapore provided cross-validation of the WIHIC, replicated the associations found between student attitudes and classroom environment perceptions in past research, and revealed differences in learning environment perception between males and females and between Chinese and Malay students.

There is considerable potential for English education researchers to replicate the lines of learning environment research that have been successfully carried out in other school subject areas (particularly science). These include: using learning environment dimensions as criteria of effectiveness in evaluating educational programs (Afari et al. 2013); further studies of outcome-environment associations (McRobbie and Fraser 1993); and using feedback on students' perceptions of actual and preferred learning environment in teacher action research aimed at improving classrooms (Fraser and Aldridge 2017).

In Singapore, because voice seldom is given to children in deciding the direction of their English lessons and choosing materials and resources, this study of classroom environments through students' eyes offers a platform for the voices of children to be heard 
and provides guidance to educators in improving the teaching and learning of primary-school English. 


\section{References}

Afari, E., Aldridge, J. M., Fraser, B. J., \& Khine, M. S. (2013). Students' perceptions of the learning environment and attitudes in game-based mathematics classrooms. Learning Environments Research, 16, 131-150.

Aldridge, J. M., \& Fraser, B. J. (2008). Outcomes-focused learning environments: Determinants and effects (Advances in Learning Environments research series). Rotterdam, The Netherlands: Sense Publishers.

Aldridge, J. M., Fraser, B. J., Bell, L., \& Dorman, J. (2012). Using a new learning environment questionnaire for reflection in teacher action research. Journal of Science Teacher Education, 23(3), 259-290.

Aldridge, J. M., Fraser, B. J., \& Huang, I. T.-C. (1999). Investigating classroom environments in Taiwan and Australia with multiple research methods. Journal of Educational Research, 93, 48-62.

Aldridge, J.M., Fraser, B.J., \& Sebela, M.P. (2004). Using teacher action research to promote constructivist learning environments in South Africa. South African Journal of Education, 24(4), 245-253.

Alzubaidi, E., Aldridge, J. M., \& Khine, M. S. (2016). Learning English as a second language at the university level in Jordan: Motivation, self-regulation and learning environment perceptions. Learning Environments Research, 19(1), 133-152.

Bi, X. (2015). Associations between psychosocial aspects of English classroom environments and motivation types of Chinese tertiary-level English majors. Learning Environments Research, 18(1), 95-110.

Burden, R.L., \& Fraser, B.J. (1993). Use of classroom environment assessments in school psychology: A British perspective. Psychology in the Schools, 30(3), 232-240.

Byrne, D.B., Hattie, J.A., \& Fraser, B.J. (1986). Student perceptions of preferred classroom learning environment. The Journal of Educational Research, 80(1), 10-18.

Chionh, Y. H., \& Fraser, B J. (2009). Classroom environment, achievement, attitudes and self esteem in geography and mathematics in Singapore. International Research in Geographical and Environmental Education, 18, 29-44.

Cohn, S. T., \& Fraser, B. J. (2016). Effectiveness of student response systems in terms of learning environment, attitudes and achievement. Learning Environments Research, 19, 153-167. 
Cohen, J. (1988). Statistical power analysis for the behavioral sciences (2nd ed.). Hillsdale, NJ: Lawrence Erlbaum Associates.

Cronbach, D. J. (1951). Coefficient alpha and internal structure of tests. Psychometrika, 16, 297-334.

De Vellis, R. F. (1991). Scale development: Theory and application. Newbury Park, CA: Sage Publications.

Dorman, J. P. (2003). Cross-national validation of the What Is Happening In this Class? (WIHIC) questionnaire using confirmatory factor analysis. Learning Environments Research, 6, 231-245.

Ebrahimi, N. A. (2015). Validation and application of the Constructivist Learning Environment Survey in English language teacher education classrooms in Iran. Learning Environments Research, 18(1), 69-93.

Ebrahimi, N. A., \& Rahimi, A. (2013). Towards a more efficient EFL reading comprehension classroom environment: The role of content and critical reading. Apples-Journal of Applied Language Studies, 7(2), 1-15.

Fraser, B.J. (1978). Development of a test of science related attitudes. Science Education, 62, 509-515.

Fraser, B.J. (1981a). Using environmental assessments to make better classrooms. Journal of Curriculum Studies, 13(2), 131-144.

Fraser, B.J. (1981b). Test of Science-Related Attitudes handbook (TOSRA). Melbourne, Australia: Australian Council for Educational Research.

Fraser, B.J. (1982). Individualized classroom environment questionnaire. American Journal of Evaluation, 3(2), 72-73.

Fraser, B.J. (1998). Classroom environment instruments: Development, validity and applications. Learning Environments Research, 1, 7-33.

Fraser, B. J. (2012). Classroom learning environments: Retrospect, context and prospect. In B. J., Fraser, K. G. Tobin, and C. J. McRobbie (Eds.), Second international handbook of science education (pp. 1191-1232). New York: Springer.

Fraser, B.J. (2014). Classroom learning environments: Historical and contemporary perspectives. In N.G. Lederman and S.K. Abell (Eds.), Handbook of research on science education, Volume II (pp. 104-119). New York: Routledge.

Fraser, B.J., \& Aldridge, J.M. (2017). Improving classrooms through assessment of learning environments. In J.P. Bakken (Ed.), Classrooms Volume 1: Assesment practices for teachers and student improvement strategies (pp. 91-107). New York: Nova. 
Fraser. B.J., \& Butts, W.L. (1982). Relationship between perceived levels of classroom individualization and science-related attitudes. Journal of Research in Science Teaching, 19(2), 143-154.

Fraser, B.J., \& Fisher, D.L. (1983). Development and validation of short forms of some instruments measuring student perceptions of actual and preferred classroom learning environment. Science Education, 67 (1), 115-131.

Fraser, B.J., Giddings, G.J., \& McRobbie, C.J. (1995). Evolution and validation of a personal form of an instrument for assessing science laboratory classroom environments. Journal of Research in Science Teaching, 32(4), 399-422.

Fraser, B. J., \& Kahle, J. B. (2007). Classroom, home and peer environment influences on student outcomes in science and mathematics: An analysis of systemic reform data. International Journal of Science Education, 29, 1891-1909.

Fraser, B.J., McRobbie, C. J., \& Fisher, D.L. (1996, April). Development, validation and use of personal and class forms of a new classroom environment instrument. Paper presented at the annual meeting of the American Educational Research Association, New York.

Fraser, B.J., \& Tobin, K.G. (Eds.). (1987). Exemplary practice in science and mathematics education. Perth: Key Centre for Teaching and Research in School Science and Mathematics, Curtin University.

Fraser, B. J., Treagust, D. F., \& Dennis, N. C. (1986). Development of an instrument for assessing classroom psychosocial environment at universities and colleges. Studies in Higher Education, 11, 43-54.

Gedamu, A. D., \& Siyawik, Y. A. (2014). The relationship between students' perceived EFL classroom climate and their achievement in English language. Science, Technology and Arts Research Journal, 3(4), 187-192.

Goh, S.C., \& Fraser, B.J. (2000). Teacher interpersonal behaviour and elementary students' outcomes. Journal of Research in Childhood Education, 14(2), 216-231.

Harris, L. (2013). An examination of 8th grade students' perceptions of learning environment in relation to their academic performance. Unpublished doctoral thesis, Northeastern University.

Helding, K.A., \& Fraser, B.J. (2013). Effectiveness of NBC (National Board Certified) teachers in terms of learning environment, attitudes and achievement among secondary school students. Learning Environments Research, 16, 1-21. 
Jannati, M., \& Marzban, A. (2015). Iranian EFL learners' perception of learning environment in English language institutes and its relationship with learners' English proficiency. Journal of Applied Linguistics and Language Research, 2(3), 23-38.

Jinks, J.L., \& Morgan, V. (1999). Children's perceived academic self-efficacy: An inventory scale. Clearing House, 72, 224-230.

Khajavy, G. H., Ghonsooly, B., Hosseini Fatemi, A., \& Choi, C. W. (2016). Willingness to communicate in English: A microsystem model in the Iranian EFL classroom context. TESOL Quarterly, 50(1), 154-180.

Khine, M.S., Fraser, B.J., Afari, E., Oo, Z., \& Kyaw, T.T. (in press). Student perceptions of the learning environment in tertiary science classrooms in Myanmar. Learning Environments Research. doi 10.10077s10984-017-9250-0

Koh, N.K., \& Fraser, B.J. (2014). Learning environments associated with use of mixed mode delivery model among secondary business studies students in Singapore. Learning Environments Research, 17, 157-171.

Lewin, K. (1936). Principles of topological psychology. New York: McGraw.

Liu, L., \& Fraser, B. J. (2013). Development and validation of an English classroom learning environment inventory and its application in China. In M.S. Khine (Ed.), Application of structural equation modeling in educational research and practice (pp. 75-89). Rotterdam, The Netherlands: Sense Publishers.

Maulana, R., Opdenakker, M. C., den Brok, P., \& Bosker, R. (2011). Teacher-student interpersonal relationships in Indonesia: profiles and importance to student motivation. Asia Pacific Journal of Education, 31(01), 33-49.

McRobbie, C. J., \& Fraser, B. J. (1993). Associations between student outcomes and psychosocial science environment. The Journal of Educational Research, 87(2), 7885.

Moos, R.H. \& Trickett, E.J. (1974). Classroom Environment Scale manual. Palo Alto, CA: Consulting Psychologists Press.

Murray, H.A. (1938). Explorations in personality. New York: Oxford University Press.

Peng, J. E., \& Woodrow, L. (2010). Willingness to communicate in English: A model in the Chinese EFL classroom context. Language Learning, 60(4), 834-876.

Safa, M. A., \& Doosti, M. (2017). A culturally-adaptive Iranian version of the Questionnaire on Teacher Interaction to investigate English teachers' interpersonal behaviour. Learning Environments Research, 20(2), 199-219. 
Sink, C. A., \& Spencer, L. R. (2005). My Class Inventory - Short Form as an accountability tool for elementary school counsellors to measure classroom climate. Professional School Counselling, 9, 37-48.

Spinner, H., \& Fraser, B.J. (2005). Evaluation of an innovative mathematics program in terms of classroom environment, student attitudes and conceptual development. International Journal of Science and Mathematics Education, 3(2), 267-293.

Sun, Y.M. (2009). A study on oral English classroom environment of university undergraduates - An empirical study based on learners psychosocial perception. Journal of Higher Education, 30(5), 71-77.

Sun, Y.M. (2010). Investigation and Research on Comprehensive English Classroom Environment in University. Foreign Language Teaching and Research, 42(6), 438444.

Tulloch, D. (2011). Determinants and effects of the learning environment in college classes. Unpublished thesis, Curtin University of Technology.

Taylor, P. C., Fraser, B. J., \& Fisher, D. L. (1997). Monitoring constructivist classroom learning environments.International Journal of Educational Research, 27, 293-302.

Teh, G.P.L., \& Fraser, B.J. (1995). Development and validation of an instrument for assessing the psychosocial environment of computer-assisted learning classrooms. Journal of Educational Computing Research, 12(2), 177-193.

Walberg, H. J., \& Anderson, G.J. (1968). Classroom climate and individual learning. Journal of Educational Psychology, 59, 414-419.

Waxman, H. C., \& Huang, S. Y. L. (1998). Classroom learning environments in urban elementary, middle, and high schools. Learning Environments Research, 1(1), 95113.

Wei, M., den Brok, P., \& Zhou, Y. (2009). Teacher interpersonal behaviour and student achievement in English as a Foreign Language classrooms in China. Learning Environments Research, 12(3), 157-174.

Wei, L.S., \& Elias, H. (2011). Relationship between students' perceptions of classroom environment and their motivation in learning English language. International Journal of Humanities and Social Science, 1(21), 240-250.

Wilks, D. R. (2000). An evaluation of classroom learning environments using critical constructivist perspectives as a referent for reform. Unpublished thesis, Curtin University of Technology. 
Wubbels, T., \& Brekelmans, M. (2005). Two decades of research on teacher-student relationships in class. International Journal of Educational Research, 43, 6-24.

Wubbels, Th., \& Brekelmans, M. (2012). Teacher-students relationships in the classroom. In B. J., Fraser, K. G. Tobin, and C. J. McRobbie (Eds.), Second international handbook of science education (pp. 1241-1255). New York: Springer.

Yarrow, A., Millwater, J. \& Fraser, B.J. (1997). Improving university and primary school classroom environments through preservice teachers' action research. International Journal of Practical Experiences in Professional Education, 1, 68-93.

Zaragoza, J. M., \& Fraser, B. J. (2017). Field-study science classrooms as positive and enjoyable learning environments. Learning Environments Research, 20(1), 1-20. 
Table 1 Learning environment research in English education

\begin{tabular}{|c|c|c|c|}
\hline Reference & Sample & $\begin{array}{l}\text { Learning } \\
\text { environment } \\
\text { instrument }\end{array}$ & Main findings \\
\hline $\begin{array}{l}\text { Safa and Doosti } \\
\text { (2017) }\end{array}$ & $\begin{array}{l}\text { Iran: } 573 \text { secondary-school } \\
\text { English students and } 32 \\
\text { teachers of English }\end{array}$ & $\begin{array}{l}\text { Modified } \\
\text { Persian version } \\
\text { of QTI }\end{array}$ & $\begin{array}{l}\text { Iranian QTI was validated. } \\
\text { Iranian students perceived their English teachers to be } \\
\text { Tolerant and Authoritative. } \\
\text { Significant difference between students' actual and } \\
\text { ideal perceptions and between students' perceptions } \\
\text { and teachers' self-perceptions of teachers' } \\
\text { interpersonal behaviour. }\end{array}$ \\
\hline $\begin{array}{l}\text { Alzubaidi, } \\
\text { Aldridge and } \\
\text { Khine (2016) }\end{array}$ & $\begin{array}{l}\text { Jordan: } 994 \text { university } \\
\text { students of English as a } \\
\text { second language }\end{array}$ & $\begin{array}{l}\text { Modified } \\
\text { Arabic version } \\
\text { of WIHIC }\end{array}$ & $\begin{array}{l}\text { Validated modified WIHIC. } \\
\text { Statistically-significant and positive bivariate and } \\
\text { multivariate associations between students' perceptions } \\
\text { of their learning environment and their motivation and } \\
\text { self-regulation. }\end{array}$ \\
\hline $\begin{array}{l}\text { Khajavy, } \\
\text { Ghonsooly, } \\
\text { Hosseini and } \\
\text { Choi (2016) }\end{array}$ & $\begin{array}{l}\text { Iran: } 243 \text { university } \\
\text { students majoring in } \\
\text { English }\end{array}$ & $\begin{array}{l}\text { Persian version } \\
\text { of } 3 \text { scales } \\
\text { from WIHIC }\end{array}$ & $\begin{array}{l}\text { Persian WIHIC scales were validated. } \\
\text { Classroom environment predicted willingness to and } \\
\text { confidence in communicating in English and attitudes. }\end{array}$ \\
\hline $\mathrm{Bi}(2015)$ & $\begin{array}{l}\text { China: } 945 \text { English majors, } \\
\text { aged } 18-20 \text { years }\end{array}$ & $\begin{array}{l}\text { Modified } \\
\text { version of } \\
\text { WIHIC }\end{array}$ & $\begin{array}{l}\text { Task Orientation, Involvement, and Teacher Support } \\
\text { were positively linked to stronger English learning } \\
\text { motivation. }\end{array}$ \\
\hline Ebrahimi (2015) & $\begin{array}{l}\text { Iran: } 622 \text { EL student } \\
\text { teachers }\end{array}$ & $\begin{array}{l}\text { Modified } \\
\text { version of } \\
\text { CLES }\end{array}$ & $\begin{array}{l}\text { Validated an English language teacher education (LTE) } \\
\text { version of CLES. } \\
\text { Iranian English language student teachers were not } \\
\text { satisfied with their current/actual classroom } \\
\text { environments and preferred more constructivist } \\
\text { classroom environments. }\end{array}$ \\
\hline $\begin{array}{l}\text { Jannati and } \\
\text { Marzban (2015) }\end{array}$ & $\begin{array}{l}\text { Iran: } 100 \text { EFL students }(50 \\
\text { males, } 50 \text { females) aged } \\
15-25 \text { years }\end{array}$ & $\begin{array}{l}\text { Modified } \\
\text { version of } \\
\text { WIHIC }\end{array}$ & $\begin{array}{l}\text { Significant relationship between male and female } \\
\text { perceptions of actual learning environment and English } \\
\text { proficiency. }\end{array}$ \\
\hline $\begin{array}{l}\text { Gedamu and } \\
\text { Siyawik (2014) }\end{array}$ & $\begin{array}{l}\text { Ethopia: } 200 \text { Grade } 10 \mathrm{EFL} \\
\text { students in preparatory and } \\
\text { secondary schools }\end{array}$ & $\begin{array}{l}\text { Based partly on } \\
\text { MCI }\end{array}$ & $\begin{array}{l}\text { Positive and significant relationships between students' } \\
\text { perceived English classroom climate and achievement. } \\
\text { Task Challenge was strongest predictor of English } \\
\text { language achievement. }\end{array}$ \\
\hline Harris (2013) & $\begin{array}{l}\text { USA (New England): grade } \\
8 \text { English students }\end{array}$ & COLES & $\begin{array}{l}\text { COLES was validated. } \\
\text { Large and statistically significant differences between } \\
\text { actual and preferred scores on all scales. } \\
\text { Actual-preferred differences were larger for females } \\
\text { than males for Teacher Support and Involvement. } \\
\text { Correlations between writing achievement and actual-- } \\
\text { preferred differences on COLES scales were weak } \\
\text { except for Task Focus. }\end{array}$ \\
\hline
\end{tabular}




\begin{tabular}{|c|c|c|c|}
\hline Reference & Sample & $\begin{array}{l}\text { Learning } \\
\text { environment } \\
\text { instrument }\end{array}$ & Main findings \\
\hline $\begin{array}{l}\text { Liu and Fraser } \\
\text { (2013) }\end{array}$ & $\begin{array}{l}\text { China: } 1,235 \text { high school } \\
\text { students, grades } 7,8,10 \\
\text { and } 11\end{array}$ & $\begin{array}{l}\text { Self-developed } \\
\text { Chinese } \\
\text { ECLEI (based } \\
\text { largely on } \\
\text { WIHIC) }\end{array}$ & $\begin{array}{l}\text { ECLEI was validated. } \\
\text { Students had positive perceptions of their English } \\
\text { classroom learning environments that became less } \\
\text { positive in higher grades. } \\
\text { Female students' perceptions were generally more } \\
\text { positive than those of the males, especially for Student } \\
\text { Cohesiveness. } \\
\text { Associations were found between the learning } \\
\text { environment and student achievement and attitudes. }\end{array}$ \\
\hline $\begin{array}{l}\text { Ebrahimi and } \\
\text { Rahimi (2013) }\end{array}$ & $\begin{array}{l}\text { Iran: } 41 \text { EFL students }(23 \\
\text { females, } 18 \text { males) aged } \\
21-27 \text { years }\end{array}$ & WIHIC & $\begin{array}{l}\text { Critical approach to teaching reading and change of } \\
\text { reading materials positively affected changes in the } \\
\text { reading comprehension classroom environment. }\end{array}$ \\
\hline $\begin{array}{l}\text { Maulana, } \\
\text { Opdenakker, den } \\
\text { Brok and Bosker } \\
\text { (2011) }\end{array}$ & $\begin{array}{l}\text { Indonesia: } 1900 \text { grades } 7-9 \\
\text { EFL and mathematics } \\
\text { students }\end{array}$ & $\begin{array}{l}\text { Indonesian } \\
\text { version of QTI }\end{array}$ & $\begin{array}{l}\text { A variety of interpersonal profiles were distinguished. } \\
\text { Teachers perceived themselves more favourably than } \\
\text { their students did. } \\
\text { Students' perceptions of teacher interpersonal } \\
\text { behaviour and their learning motivation were related. } \\
\text { Influence and Proximity were found to be important } \\
\text { determinants of student motivation. }\end{array}$ \\
\hline $\begin{array}{l}\text { Wei and Elias } \\
\text { (2011) }\end{array}$ & $\begin{array}{l}\text { Malaysia: } 140 \text { Form } 4 \\
\text { students }\end{array}$ & CES & $\begin{array}{l}\text { Several classroom environment scales were correlated } \\
\text { weakly with student motivation. }\end{array}$ \\
\hline Tulloch (2011) & $\begin{array}{l}\text { USA (Florida): } 544 \text { junior } \\
\text { college students }\end{array}$ & $\begin{array}{l}\text { Modified } \\
\text { CLES }\end{array}$ & $\begin{array}{l}\text { Modified CLES was validated. } \\
\text { While no significant sex differences were found, } \\
\text { females enjoyed their classrooms somewhat more than } \\
\text { did males. } \\
\text { Relative to younger students, older students had higher } \\
\text { Student Negotiation and Enjoyment scores. } \\
\text { Student enjoyment and perceptions of classroom } \\
\text { environment were positively associated. }\end{array}$ \\
\hline $\begin{array}{l}\text { Peng and } \\
\text { Woodrow } \\
(2010)\end{array}$ & $\begin{array}{l}\text { China: Groups of } 330 \text { and } \\
579 \text { EFL university } \\
\text { students }\end{array}$ & $\begin{array}{l}\text { Chinese } \\
\text { version of } 3 \\
\text { WIHIC scales }\end{array}$ & $\begin{array}{l}\text { Chinese WIHIC scales were validated. } \\
\text { Classroom environment predicted willingness to and } \\
\text { confidence in communicating in English. }\end{array}$ \\
\hline Sun (2010) & $\begin{array}{l}\text { China: } 745 \text { university } \\
\text { English students }\end{array}$ & $\begin{array}{l}\text { Chinese } \\
\text { version of } 9 \\
\text { modified scales } \\
\text { from WIHIC, } \\
\text { CES, QTI and } \\
\text { CUCEI }\end{array}$ & $\begin{array}{l}\text { Questionnaire was validated. } \\
\text { Teacher perceived classrooms more positively than } \\
\text { students. } \\
\text { Females had more positive perceptions than males on } \\
\text { several scales. } \\
\text { Weak associations between English achievement and } \\
\text { classroom environment. }\end{array}$ \\
\hline
\end{tabular}




\begin{tabular}{|c|c|c|c|}
\hline Reference & Sample & $\begin{array}{l}\text { Learning } \\
\text { environment } \\
\text { instrument }\end{array}$ & Main findings \\
\hline Sun (2009) & $\begin{array}{l}\text { China: } 418 \text { oral EFL } \\
\text { university students }\end{array}$ & $\begin{array}{l}\text { Chinese } \\
\text { version of } 9 \\
\text { modified scales } \\
\text { from WIHIC, } \\
\text { CES, QTI and } \\
\text { CUCEI }\end{array}$ & $\begin{array}{l}\text { Questionnaire was validated. } \\
\text { Teachers perceived classrooms more positively than } \\
\text { students. } \\
\text { Gender differences in perceptions were small. } \\
\text { Weak associations between oral English performance } \\
\text { and classroom environment. }\end{array}$ \\
\hline $\begin{array}{l}\text { Wei, den Brok } \\
\text { and Zhou (2009) }\end{array}$ & $\begin{array}{l}\text { China: } 160 \text { grade } 8 \text { English } \\
\text { students }\end{array}$ & $\begin{array}{l}\text { Chinese } \\
\text { version of QTI }\end{array}$ & $\begin{array}{l}\text { Chinese QTI was validated. } \\
\text { Differences between actual and preferred scores. } \\
\text { Weak associations between QTI scores and } \\
\text { achievement. } \\
\text { Tolerant-authoritative was the major teacher } \\
\text { interpersonal style. }\end{array}$ \\
\hline Wilks (2000) & $\begin{array}{l}\text { Singapore: } 1046 \text { students in } \\
48 \text { junior college 'General } \\
\text { Paper' English classes }\end{array}$ & $\begin{array}{l}\text { Modified } \\
\text { version of } \\
\text { CLES }\end{array}$ & $\begin{array}{l}\text { Modified CLES was validated. } \\
\text { Teaching and learning environment in English classes } \\
\text { was consistent with critical constructivism. }\end{array}$ \\
\hline $\begin{array}{l}\text { Waxman and } \\
\text { Huang (1998) }\end{array}$ & $\begin{array}{l}\text { USA: } 13,000 \text { elementary, } \\
\text { middle, and high school } \\
\text { students }\end{array}$ & Modified CES & $\begin{array}{l}\text { Female students perceived their learning environment } \\
\text { more favourably than did male students. } \\
\text { Middle-school students perceived their learning } \\
\text { environment less favourably than elementary- or high- } \\
\text { school students. }\end{array}$ \\
\hline
\end{tabular}

Abbreviations used in order of mention (for LE instruments):

QTI Questionnaire on Teacher Interaction (Wubbels and Brekelmans 2005)

WIHIC What Is Happening In this Class? questionnaire (Fraser et al. 1996)

CLES Constructivist Learning Environment Survey (Taylor et al. 1997)

MCI My Class Inventory (Sink and Spencer 2005)

COLES Constructivist-Oriented Learning Environment Survey (Aldridge et al. 2012)

ECLEI English Classroom Environment Inventory (Liu and Fraser 2013)

CES Classroom Environment Scale (Moos and Trickett 1974)

CUCEI College and University Classroom Environment Inventory (Fraser et al. 1986) 
Table 2 Factor analysis and internal consistency reliability for learning environment questionnaire

(WIHIC)

\begin{tabular}{|c|c|c|c|c|c|c|}
\hline \multirow[t]{2}{*}{ Item } & \multicolumn{6}{|c|}{ Factor Loadings } \\
\hline & $\begin{array}{c}\text { Student } \\
\text { Cohesiveness }\end{array}$ & $\begin{array}{l}\text { Teacher } \\
\text { Support }\end{array}$ & Involvement & $\begin{array}{c}\text { Task } \\
\text { Orientation }\end{array}$ & Cooperation & Equity \\
\hline 1 & 0.58 & & & & & \\
\hline 2 & 0.43 & & & & & \\
\hline 3 & 0.53 & & & & & \\
\hline 4 & 0.67 & & & & & \\
\hline 5 & 0.52 & & & & & \\
\hline 6 & 0.43 & & & & & \\
\hline 7 & 0.54 & & & & & \\
\hline 9 & & 0.68 & & & & \\
\hline 10 & & 0.64 & & & & \\
\hline 11 & & 0.67 & & & & \\
\hline 12 & & 0.65 & & & & \\
\hline 13 & & 0.66 & & & & \\
\hline 14 & & 0.59 & & & & \\
\hline 15 & & 0.51 & & & & \\
\hline 16 & & 0.45 & & & & \\
\hline 17 & & & 0.53 & & & \\
\hline 18 & & & 0.64 & & & \\
\hline 19 & & & 0.41 & & & \\
\hline 20 & & & 0.64 & & & \\
\hline 21 & & & 0.57 & & & \\
\hline 22 & & & 0.57 & & & \\
\hline 23 & & & 0.40 & & & \\
\hline 24 & & & 0.41 & & & \\
\hline 25 & & & & 0.68 & & \\
\hline 26 & & & & 0.62 & & \\
\hline 27 & & & & 0.62 & & \\
\hline 28 & & & & 0.67 & & \\
\hline 29 & & & & 0.62 & & \\
\hline 30 & & & & 0.45 & & \\
\hline 31 & & & & 0.53 & & \\
\hline 32 & & & & 0.66 & & \\
\hline 33 & & & & & 0.49 & \\
\hline 34 & & & & & 0.44 & \\
\hline 35 & & & & & 0.60 & \\
\hline 36 & & & & & 0.65 & \\
\hline 37 & & & & & 0.59 & \\
\hline 38 & & & & & 0.69 & \\
\hline 39 & & & & & 0.59 & \\
\hline 40 & & & & & 0.52 & \\
\hline 41 & & & & & & 0.51 \\
\hline 42 & & & & & & 0.65 \\
\hline 43 & & & & & & 0.67 \\
\hline 44 & & & & & & 0.70 \\
\hline 45 & & & & & & 0.65 \\
\hline 46 & & & & & & 0.65 \\
\hline 47 & & & & & & 0.58 \\
\hline 48 & & & & & & 0.49 \\
\hline$\%$ Variance & 2.77 & 3.79 & 7.74 & 3.38 & 32.91 & 5.02 \\
\hline Eigenvalue & 1.33 & 1.81 & 3.71 & 1.62 & 15.79 & 2.41 \\
\hline Alpha & 0.81 & 0.88 & 0.86 & 0.88 & 0.91 & 0.92 \\
\hline Reliability & & & & & & \\
\hline
\end{tabular}


Table 3 Factor analysis and internal consistency reliability for attitude scales

\begin{tabular}{ccc}
\hline Item & \multicolumn{2}{c}{ Factor Loadings } \\
\cline { 2 - 3 } & Attitude to English Language & Academic Efficacy \\
\hline 1 & 0.80 & \\
3 & 0.86 & \\
4 & 0.86 & \\
5 & 0.88 & \\
6 & 0.76 & \\
7 & 0.85 & \\
8 & 0.72 & \\
9 & 0.82 & 0.65 \\
10 & & 0.81 \\
11 & & 0.68 \\
12 & & 0.72 \\
13 & & 0.79 \\
14 & & 0.71 \\
16 & & 0.58 \\
E Variance & 0.67 \\
Eigenvalue & & 17.31 \\
Alpha Reliability & 51.55 & 2.77 \\
& 8.49 & 0.90 \\
\hline
\end{tabular}

$N=441$ students in 22 classes.

Factor loadings less than 0.40 have been omitted from the table.

Principal axis factoring with varimax rotation and Kaiser normalization. 
Table 4 Average item mean, average item standard deviation and gender difference (effect size and ANOVA result) for each learning environment and attitude scale

\begin{tabular}{|c|c|c|c|c|c|c|}
\hline \multirow[t]{2}{*}{ Scale } & \multicolumn{2}{|c|}{ Average Item Mean } & \multicolumn{2}{|c|}{ Average Item SD } & \multicolumn{2}{|c|}{ Difference } \\
\hline & Male & Female & Male & Female & Effect Size & $F$ \\
\hline \multicolumn{7}{|l|}{ Learning Environment } \\
\hline Student Cohesiveness & 4.01 & 4.11 & 0.63 & 0.52 & 0.17 & 1.37 \\
\hline Teacher Support & 3.81 & 3.93 & 0.72 & 0.77 & 0.16 & 1.31 \\
\hline Involvement & 3.53 & 3.56 & 0.74 & 0.69 & 0.04 & 0.62 \\
\hline Task Orientation & 4.13 & 4.35 & 0.65 & 0.53 & 0.37 & $1.95^{* *}$ \\
\hline Cooperation & 3.91 & 4.14 & 0.66 & 0.63 & 0.35 & $1.89 * *$ \\
\hline Equity & 3.84 & 3.89 & 0.78 & 0.81 & 0.06 & 0.75 \\
\hline \multicolumn{7}{|l|}{ Attitudes } \\
\hline Attitude to English Language & 3.84 & 3.97 & 0.99 & 0.91 & 0.13 & 1.20 \\
\hline Academic Efficacy & 3.11 & 3.17 & 0.87 & 0.93 & 0.07 & 0.82 \\
\hline
\end{tabular}

$* * p<0.01$

males $(n=202)$; females $(n=232)$ 
Table 5 Average item mean, average item standard deviation and ethnic difference (effect size and ANOVA result) for each learning environment and attitude scale

\begin{tabular}{|c|c|c|c|c|c|c|}
\hline \multirow[t]{2}{*}{ Scale } & \multicolumn{2}{|c|}{ Average Item Mean } & \multicolumn{2}{|c|}{ Average Item SD } & \multicolumn{2}{|c|}{ Difference } \\
\hline & Chinese & Malay & Chinese & Malay & Effect Size & $F$ \\
\hline \multicolumn{7}{|l|}{ Learning Environment } \\
\hline Student Cohesiveness & 4.01 & 4.11 & 0.61 & 0.39 & 0.19 & 1.22 \\
\hline Teacher Support & 3.79 & 4.02 & 0.73 & 0.64 & 0.33 & $1.62 * *$ \\
\hline Involvement & 3.46 & 3.68 & 0.73 & 0.62 & 0.32 & $1.61 * *$ \\
\hline Task Orientation & 4.21 & 4.26 & 0.59 & 0.61 & 0.08 & 0.81 \\
\hline Cooperation & 4.01 & 4.05 & 0.67 & 0.57 & 0.06 & 0.76 \\
\hline Equity & 3.81 & 3.91 & 0.83 & 0.57 & 0.14 & 1.04 \\
\hline \multicolumn{7}{|l|}{ Attitudes } \\
\hline Attitude to English Language & 3.78 & 4.24 & 0.98 & 0.72 & 0.53 & $2.01 * *$ \\
\hline Academic Efficacy & 3.04 & 3.19 & 0.90 & 0.75 & 0.18 & 1.20 \\
\hline
\end{tabular}

$* * p<0.01$

Chinese $(n=279)$; Malay $(n=89)$ 
Table 6 Simple correlation and multiple regression analyses for associations between learning environment and attitude scales

\begin{tabular}{|c|c|c|c|c|}
\hline \multirow{3}{*}{ Scale } & \multicolumn{4}{|c|}{ Attitude-Environment Associations } \\
\hline & \multicolumn{2}{|c|}{ Attitude to English } & \multicolumn{2}{|c|}{ Academic Efficacy } \\
\hline & $r$ & $\beta$ & $r$ & $\beta$ \\
\hline Student Cohesiveness & $0.25 * *$ & 0.08 & $0.32 * *$ & 0.07 \\
\hline Teacher Support & $0.45^{* *}$ & $0.17 * *$ & $0.27 * *$ & 0.03 \\
\hline Involvement & $0.40 * *$ & $0.14^{*}$ & $0.39 * *$ & $0.22 * *$ \\
\hline Task Orientation & $0.43 * *$ & $0.18 * *$ & $0.29 * *$ & 0.03 \\
\hline Cooperation & $0.37 * *$ & 0.04 & $0.34 * *$ & 0.05 \\
\hline Equity & $0.46 * *$ & $0.18 * *$ & $0.35 * *$ & $0.19 * *$ \\
\hline Multiple Correlation, $R$ & & $0.54 * *$ & & $0.44 * *$ \\
\hline
\end{tabular}

$* p<0.05, * * p<0.01$ 